\title{
Brain Insulin Impairs Amyloid- $\beta(1-40)$ Clearance from the Brain
}

\author{
Takeshi Shiiki, ${ }^{1}$ Sumio Ohtsuki, ${ }^{2,3,4}$ Atsushi Kurihara, ${ }^{1}$ Hideo Naganuma, ${ }^{1}$ Kenji Nishimura, ${ }^{1}$ Masanori Tachikawa, ${ }^{2}$ \\ Ken-ichi Hosoya, ${ }^{4,5}$ and Tetsuya Terasaki ${ }^{2,3,4}$ \\ ${ }^{1}$ Drug Metabolism and Pharmacokinetics Research Laboratories, Sankyo Company, Shinagawa-ku, Tokyo 140-8710, Japan, ${ }^{2}$ Department of Molecular \\ Biopharmacy and Genetics, Graduate School of Pharmaceutical Sciences, and ${ }^{3}$ New Industry Creation Hatchery Center, Tohoku University, Aoba, Aramaki, \\ Aoba-ku, Sendai 980-8578, Japan, ${ }^{4}$ Solution-Oriented Research for Science and Technology of Japan Science and Technology Agency, Saitama 332-0012, \\ Japan, and ${ }^{5}$ Faculty of Pharmaceutical Sciences, Toyama Medical and Pharmaceutical University, Sugitani, Toyama 930-0194, Japan
}

Cerebral amyloid- $\beta$ peptide $(\mathrm{A} \beta)$ clearance plays a key role in determining the brain level of $A \beta$; however, its mechanism remains unclear. In this study, we investigated cerebral $A \beta$ clearance across the blood-brain barrier (BBB) by using the Brain Efflux Index method. $\left[{ }^{125} \mathrm{I}\right] \mathrm{A} \beta(1-40)$ was eliminated from rat brain to circulating blood with a half-life of $48.8 \mathrm{~min}$ and a half-saturation concentration of 8.15 nм. The $\mathrm{A} \beta(1-40)$ elimination rate was reduced by $30.5 \%$ in 23 -month-old rats compared with 7-week-old rats. The intact form of $\mathrm{A} \beta(1-40)$ was detected in plasma after intracerebral administration, indicating the occurrence of efflux transport of intact $\mathrm{A} \beta(1-40)$. The $\mathrm{A} \beta(1-40)$ elimination rate was significantly inhibited by coadministration of $100 \mu \mathrm{g} / \mathrm{ml}$ insulin and $1 \mathrm{~mm}$ thiorphan by 44.6 and $34.0 \%$, respectively. The level of intact $\left[{ }^{125} \mathrm{I}\right] \mathrm{A} \beta(1-40)$ in the brain was increased by coadministration of insulin. Among insulindegrading enzyme inhibitors, bacitracin inhibited the elimination rate, whereas $N$-ethylmaleimide and metal chelators had no effect. Receptor-associated protein, fucoidan, 3-bromo-5-t-butyl-4-hydroxy-benzylidenemalonitrile, anti-IGF-I receptor antibody, and L-tyrosine did not affect the $\mathrm{A} \beta(1-40)$ elimination rate, suggesting that the relevant receptors or transporters are not likely to be involved in the clearance. In conclusion, the present study has demonstrated the involvement of a proteolytic degradation process and an insulinsensitive process in cerebral $\mathrm{A} \beta(1-40)$ clearance in the rat.

Key words: Alzheimer's disease; amyloid- $\beta(1-40)$; amyloid- $\beta$ clearance; blood-brain barrier; Brain Efflux Index method; insulin

\section{Introduction}

Deposition of amyloid- $\beta$ peptides $(\mathrm{A} \beta)$, mainly $\mathrm{A} \beta(1-40)$ and $\mathrm{A} \beta(1-42)$, is a pathologic feature of Alzheimer's disease (AD). Generation of these peptides through proteolytic cleavage by $\beta$ and $\gamma$-secretase is well established, although the clearance mechanism of $\mathrm{A} \beta$ from the brain remains obscure. Impairment of $\mathrm{A} \beta$ clearance from the brain could have an important pathogenic role in $\mathrm{AD}$, because a large percentage of $\mathrm{AD}$ is apparently not explicable in terms of abnormalities in $\mathrm{A} \beta$ production (Selkoe, 2001). Thus, it would be beneficial to elucidate the mechanism of the cerebral clearance of $\mathrm{A} \beta$ from the standpoint of understanding and treating AD.

Brain-to-blood $A \beta$ efflux transport across the blood-brain barrier (BBB) (Shibata et al., 2000) and $\mathrm{A} \beta$ degradation by protease (Selkoe, 2001) have been reported as cerebral A $\beta$ clearance mechanisms. Shibata et al. (2000) suggested that low-density lipoprotein (LDL) receptor-related protein-1 (LRP-1) mediates $\mathrm{A} \beta(1-40)$ efflux transport at the mouse BBB on the basis of inhibition of $A \beta(1-40)$ efflux by receptor-associated protein (RAP) and antibodies against LRP-1. However, the fact that in-

Received June 26, 2003; revised Sept. 14, 2004; accepted Sept. 14, 2004.

We thank Dr. T. Iwatsubo (Tokyo University, Tokyo, Japan) for valuable discussions.

Correspondence should be addressed to Takeshi Shiiki, Drug Metabolism and Pharmacokinetics Research Laboratories, Sankyo Company, 1-2-58, Hiromachi, Shinagawa-ku, Tokyo 140-8710, Japan. E-mail: shiiki@sankyo.co.jp. DOI:10.1523/JNEUROSCI.2236-04.2004

Copyright $\odot 2004$ Society for Neuroscience $\quad$ 0270-6474/04/249632-06\$15.00/0 hibition by these proteins is only partial suggests the involvement of other mechanism(s) in $\mathrm{A} \beta(1-40)$ efflux transport at the BBB. Insulin-degrading enzyme (IDE) and neprilysin (NEP) have been reported to be involved in the extracellular degradation of $\mathrm{A} \beta$ (Qiu et al., 1998; Iwata et al., 2000). However, the relative contributions of the brain-to-blood efflux transport and proteolytic degradation to cerebral $\mathrm{A} \beta$ clearance in vivo are still unknown.

The development of the Brain Efflux Index (BEI) method (Kakee et al., 1996) allows us to investigate cerebral clearance mechanisms in rats, including brain-to-blood efflux transport systems at the BBB. Using the BEI method, specific efflux transport at the BBB for various compounds, including peptides and proteins, such as transferrin and immunoglobulin, have been investigated (Zhang and Pardridge, 2001a,b; Hosoya et al., 2002).

The purpose of the present study is to investigate the cerebral $\mathrm{A} \beta(1-40)$ clearance in rat and the involvement of efflux transport and proteolysis by IDE and NEP in this clearance by using the BEI method.

\section{Materials and Methods}

Materials. [ $\left.{ }^{125} \mathrm{I}\right]$ Amyloid $\beta$-protein $(1-40)$ ([ $\left.{ }^{125} \mathrm{I}\right] \mathrm{A} \beta(1-40), 2200 \mathrm{Ci} /$ $\mathrm{mmol}),\left[{ }^{14} \mathrm{C}\right]$ carboxyl-inulin $\left(\left[{ }^{14} \mathrm{C}\right]\right.$ inulin, $\left.2.64 \mathrm{mCi} / \mathrm{gm}\right)$, and $\left[{ }^{125} \mathrm{I}\right] \mathrm{Na}$ (17.4 mCi/mg) were purchased from PerkinElmer Life Sciences (Boston, MA). $\left[{ }^{125} \mathrm{I}\right]$ Human recombinant insulin $\left(\left[{ }^{125} \mathrm{I}\right]\right.$ insulin, $\left.2000 \mathrm{Ci} / \mathrm{mmol}\right)$ was purchased from Amersham Biosciences (Piscataway, NJ). Unlabeled A $\beta(1-$ 40) was purchased from Bachem (Bubendorf, Switzerland). Xylazine hydrochloride, chloramine-T, fucoidan from Fucus vesiculosus, DL-thiorphan, human recombinant insulin sodium salt, insulin-like growth factor-I 
(IGF-I) and IGF-II, phenylmethylsulfonyl fluoride, leupeptin, and $p$-aminobenzamidine were purchased from Sigma (St. Louis, MO). RAPwaspurchasedfromResearchDiagnostics(Flanders,NJ).3-Bromo5-t-butyl-4-hydroxy-benzylidenemalonitrile (AG1024), bacitracin, and 1,10-phenanthroline were purchased from Calbiochem (San Diego, CA). $N$-ethylmaleimide was purchased from Waco Pure Chemical Industries (Osaka, Japan). EDTA was purchased from Dojindo Laboratories (Kumamoto, Japan). All other chemicals were commercial products of reagent grade.

Antibody. Anti-IGF-I receptor (IGFIR) mouse monoclonal antibody against human IGFIR, an antibody that reacts with human, mouse, and rat IGFIR and neutralizes their bioactivities (Rohlik et al., 1987), was purchased from Oncogene Research Products (Boston, MA) for use in the experiments.

Animals. Sprague Dawley male rats (Charles River, Yokohama, Japan) were used throughout this study. Animal experiments were performed according to the guidelines provided by the Animal Care and Use Committee of Sankyo Company (Tokyo, Japan).

BEI study. The in vivo brain elimination experiments were performed by means of the intracerebral microinjection technique reported previously (Kakee et al., 1996). A 7-week-old or 23-month-old rat was anesthetized with an intramuscular injection of ketamine $(235 \mathrm{mg} / \mathrm{kg}$; Sankyo Company) and xylazine $(2.3 \mathrm{mg} / \mathrm{kg})$ and placed in a stereotaxic frame (SR-6; Narishige, Tokyo, Japan). A needle (100 $\mu \mathrm{m}$, i.d.; $350 \mu \mathrm{m}$ o.d.; Seiseido Medical Industry, Tokyo, Japan) fitted on a $5.0 \mu \mathrm{l}$ microsyringe (Hamilton, Reno, NE) was inserted into the parietal cortex, area 2 (Par2) region, through a $1.0 \mathrm{~mm}$ hole at $0.20 \mathrm{~mm}$ anterior and $5.5 \mathrm{~mm}$ lateral to the bregma and at a depth of $4.5 \mathrm{~mm}$. $\left[{ }^{125} \mathrm{I}\right] \mathrm{A} \beta(1-40)(0.02 \mu \mathrm{Ci})$ and $\left[{ }^{14} \mathrm{C}\right.$ ] inulin $(0.01 \mu \mathrm{Ci})$ dissolved in $0.5 \mu \mathrm{l}$ of extracellular fluid (ECF) buffer (122 mM NaCl, $25 \mathrm{~mm} \mathrm{NaHCO}_{3}, 3 \mathrm{~mm} \mathrm{KCl}, 1.4 \mathrm{~mm} \mathrm{CaCl}_{2}, 1.2 \mathrm{~mm}$ $\mathrm{MgSO}_{4}, 0.4 \mathrm{~mm} \mathrm{~K}_{2} \mathrm{HPO}_{4}, 10 \mathrm{~mm}$ D-glucose and $10 \mathrm{~mm}$ HEPES, pH 7.4, $290 \mathrm{mOsm} / \mathrm{kg}$ ) were administered to the brain over $30 \mathrm{sec}$. At designated times after microinjection, CSF was collected from the cisterna magna and then the ipsilateral (left) and contralateral (right) cerebrum and cerebellum were excised and dissolved in $3 \mathrm{ml}$ of tissue solubilizer, NCS-II (Amersham Biosciences), at $50^{\circ} \mathrm{C}$ overnight. Samples were mixed with $10 \mathrm{ml}$ of liquid scintillation mixture, Hionic-fluor (Packard Instruments, Meriden, CT). Radioactivity counting was performed using a double-channel system for ${ }^{125} \mathrm{I}$ and ${ }^{14} \mathrm{C}$ with a liquid scintillation counter (Tri-Carb 2300TR; Packard Instruments) over an energy range of $0-45$ kilo electron volts $(\mathrm{keV})$ for ${ }^{125} \mathrm{I}$ and $45-156 \mathrm{keV}$ for ${ }^{14} \mathrm{C}$. Overlapping of ${ }^{125} \mathrm{I}$ energy into the ${ }^{14} \mathrm{C}$ range is negligible within the ranges used.

For the inhibition study, $\left[{ }^{125} \mathrm{I}\right] \mathrm{A} \beta(1-40)$ and $\left[{ }^{14} \mathrm{C}\right]$ inulin were administered simultaneously in the presence or absence of several inhibitors as a coadministration study. The efficacy of the inhibitors might be limited because of dilution of the injectate in the brain after the microinjection. To minimize the dilution of inhibitors in the brain, a preadministration study was performed. For the preadministration study, 50.0 $\mu \mathrm{l}$ of inhibitor was administered into the Par2 region over $30 \mathrm{sec}$ just before microinjection of $\left[{ }^{125} \mathrm{I}\right] \mathrm{A} \beta(1-40)$ and $\left[{ }^{14} \mathrm{C}\right]$ inulin into the same region. Instead of ECF buffer, 1,10-phenanthroline and EDTA were dissolved in PBS.

Determination of apparent elimination rate constant. The BEI value is defined as shown by Equation 1, and the percentage of substrate remaining in the ipsilateral cerebrum, $(100-\mathrm{BEI}) \%$, was determined using Equation 2 as follows:

$$
\text { BEI }(\%)=\frac{(\text { test substrate undergoing efflux at the BBB })}{(\text { test substrate injected into the brain })} \times 100 \text {, }
$$

$$
100-\text { BEI }(\%)=\frac{\left(\frac{\text { amount of test substrate in the brain }}{\text { amount of reference in the brain }}\right)}{\left(\frac{\text { amount of test substrate injected }}{\text { amount of reference injected }}\right)} \times 100 .
$$

The apparent elimination rate constant, $k_{\text {app,el }}$, was estimated by linear regression analysis of the semilogarythmic plot of $(100-\mathrm{BEI}) \%$ versus time. Kinetic parameters of efflux transport were calculated by using Equation $3, k_{\mathrm{app}, \mathrm{el}}=k_{\mathrm{el}, \text { max }} /\left(K_{\mathrm{m}}+C\right)+k_{\mathrm{el}, \mathrm{NS}}$, where $k_{\mathrm{el}, \max }, K_{\mathrm{m}}$, and $k_{\mathrm{el}, \mathrm{NS}}$ represent the maximum elimination rate, the half-saturation concentration, and the nonsaturable elimination rate constant, respectively. $C$ is the $\mathrm{A} \beta(1-40)$ concentration in the injectate. For the preadministration study, the elimination from the brain was evaluated as $k_{\text {app,el }}$ or the $(100-\mathrm{BEI})$ value at $60 \mathrm{~min}$ after microinjection. Regression analysis and estimation of parameters were performed using the nonlinear leastsquares regression analysis program WinNonlin Professional, version 3.1 (Pharsight, Mountain View, CA).

HPLC analysis of radioactivity in plasma. $\mathrm{A} \beta(1-40)(4.7 \mathrm{nmol})$ was iodinated with ${ }^{125} \mathrm{I}(10 \mathrm{mCi}, 4.7 \mathrm{nmol})$ and chloramine- $\mathrm{T}(200 \mathrm{nmol})$, because for detection in plasma, $\sim 30$ times more ${ }^{125}$ I radioactivity must be administered than for the BEI study. The purified $\left[{ }^{125} \mathrm{I}\right] \mathrm{A} \beta(1-40)$ had a trichloroacetic acid precipitability of $98.2 \%$. An aliquot of $0.5 \mu \mathrm{l}$ of $\left[{ }^{125} \mathrm{I}\right] \mathrm{A} \beta(1-40)\left(\sim 1.25 \times 10^{6} \mathrm{dpm}\right)$ was administered to the Par2 region as described above. A blood specimen was collected from the ipsilateral jugular vein at $5 \mathrm{~min}$ after administration. The plasma was immediately separated by centrifugation and gel-filtered on a PD-10 column (Amersham Biosciences) with $1 \mu \mathrm{M} A \beta(1-40)$ solution to avoid binding of the radiolabeled compound to the column or further metabolism. Ten drops of each eluate fraction from the PD-10 column were collected and counted using a gamma counter (RiaStar; Packard Instruments). Two major peaks in fractions 8 and 17 were analyzed by reverse-phase HPLC on a Develosil ODS UG-3 $4.6 \times 100 \mathrm{~mm}$ column (Nomura Chemical, Aichi, Japan) heated at $40^{\circ} \mathrm{C}$, with a linear gradient of $20-56 \%$ acetonitrile in $0.1 \%$ trifluoroacetate at a flow rate of $1 \mathrm{ml} / \mathrm{min}$ over $20 \mathrm{~min}$. Under these conditions, $A \beta(1-40)$ was eluted at $12.5 \mathrm{~min}$.

Ultrafiltration of injectate. Injectate of $\left[{ }^{125} \mathrm{I}\right] \mathrm{A} \beta(1-40)$ in the presence or absence of insulin $(100 \mu \mathrm{g} / \mathrm{ml})$ was filtered through an Ultrafree-MC filter (molecular weight cutoff, 5000; Millipore, Bedford, MA). Each injectate or filtrate was counted using a gamma counter. The filtrability of insulin was assessed by using [ $\left.{ }^{125} \mathrm{I}\right]$ insulin dissolved in extracellular fluid buffer $(0.02 \mathrm{mCi} / \mathrm{ml})$ instead of the injectate.

SDS-PAGE analysis of radioactivity in the brain. $\left[{ }^{125} \mathrm{I}\right] \mathrm{A} \beta(1-40)$ in the presence or absence of insulin $(100 \mu \mathrm{g} / \mathrm{ml})$ was microinjected into the Par2 region of the brain as described previously. At 30 min after microinjection, the Par2 region of the ipsilateral cerebrum was excised and frozen immediately in dry ice powder and stored at $-80^{\circ} \mathrm{C}$ until analysis. The brain tissues were homogenized in PBS, $\mathrm{pH} 7.4$, containing protease inhibitors $(0.5 \mathrm{~mm}$ phenylmethylsulfonyl fluoride, $1 \mu \mathrm{g} / \mathrm{ml}$ leupeptin, and $1 \mathrm{~mm} p$-aminobenzamidine) and then centrifuged at 20,000 $\times g$ for $3 \mathrm{~min}$ at $4^{\circ} \mathrm{C}$. The supernatant was mixed with $2 \mathrm{vol}$ of tricine sample buffer (Bio-Rad, Hercules, CA) and boiled for $3 \mathrm{~min}$. The samples were counted with a gamma counter and electrophoresed in $16.5 \%$ Tristricine gels (Bio-Rad). After SDS-PAGE, the gels were dried and exposed to a Fuji imaging plate (Fuji, Tokyo, Japan). The obtained fluorograms were analyzed using a BAS2500 bioimaging system (Fuji).

Data analysis. Statistical analyses were performed by the SAS System for Windows, Release 8.2 (SAS Institute, Cary, NC). Comparisons among the groups were made by means of the unpaired Student's $t$ test. A $p$ value of $<0.05$ was considered statistically significant.

\section{Results}

\section{A $\beta(1-40)$ elimination from rat brain}

Elimination of $\left[{ }^{125} \mathrm{I}\right] \mathrm{A} \beta(1-40)$ from rat brain was examined by means of the BEI method (Fig. 1). The relative percentage of ${ }^{125} \mathrm{I}$ radioactivity remaining in the ipsilateral cerebrum, (100 $\mathrm{BEI}) \%$, declined monoexponentially with an apparent elimination rate constant $\left(k_{\text {app,el }}\right)$ of $1.42 \times 10^{-2} \pm 0.11 \times 10^{-2} \mathrm{~min}^{-1}$ (mean \pm SEM) and a half-life of $48.8 \mathrm{~min}$ (Fig. $1 A$ ). No significant amount of radioactivity was detected in the contralateral cerebrum, cerebellum, or CSF, indicating that diffusion into the rest of the region from the injection site is limited. Furthermore, radioactivity of $\left[{ }^{14} \mathrm{C}\right]$ inulin, a nonpermeable substance, in the ipsilateral cerebrum was unchanged in the brain throughout the 
A

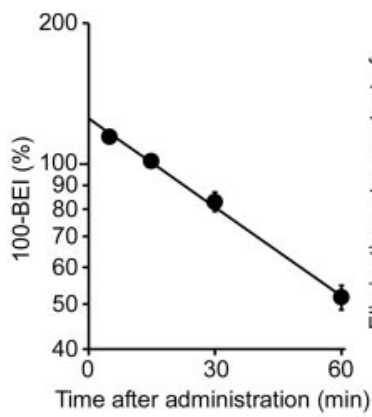

B

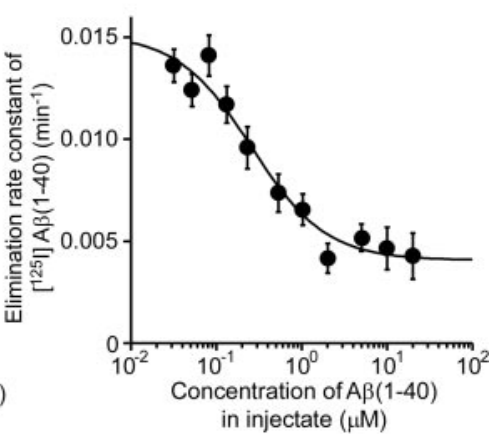

Figure 1. Time course and concentration dependence of $\left[{ }^{125} \mathrm{I}\right] \mathrm{A} \beta(1-40)$ elimination from rat brain. $A$, Time course of $\left.\left[{ }^{125}\right]\right] A \beta(1-40)$ in the ipsilateral cerebrum after intracerebral microinjection. Each point represents the mean $\pm \operatorname{SEM}(n=4)$. $B$, Concentration dependence of $\left[{ }^{125}\right.$ I] $] A \beta(1-40)$ elimination rate from rat brain. The $A \beta(1-40)$ concentration in the injectate is indicated. Each point represents the mean $\pm \operatorname{SEM}(n=3-8)$. Kinetic parameters of the concentration- elimination rate constant curve were calculated as $k_{\text {eff } \max }=2.79 \times 10^{-3} \pm$ $0.84 \times 10^{-3} \mu \mathrm{m} / \mathrm{min}, K_{\mathrm{m}}=0.247 \pm 0.083 \mu \mathrm{M}$, and $k_{\text {eff,Ns }}=4.04 \times 10^{-3} \pm 0.50 \times 10^{-3}$ $\min ^{-1}$ (mean \pm SEM).

experiment (values of percentage recovery at 5 and 60 min were $64.3 \pm 3.6$ and $61.8 \pm 4.0 \%$, respectively; $n=4$; mean \pm SEM), suggesting that the BBB was not damaged by the microinjection procedure. Therefore, this elimination rate reflects the elimination efficiency of $\mathrm{A} \beta(1-40)$ from the brain to the blood across the BBB.

The elimination rate of $\left[{ }^{125} \mathrm{I}\right] \mathrm{A} \beta(1-40)$ was concentration dependent (Fig. 1 B). Even at the highest concentration of $20 \mu \mathrm{M}$ unlabeled $\mathrm{A} \beta(1-40)$, the $k_{\text {app,el }}$ value remained at $28.9 \%$ of the maximum $k_{\text {app,el }}$, indicating that the elimination of [ $\left.{ }^{125} \mathrm{I}\right] \mathrm{A} \beta(1-$ 40) was composed of saturable and nonsaturable components. The half-saturation concentration $\left(K_{\mathrm{m}}\right)$ of the saturable component was $0.247 \mu \mathrm{M}$ (injectate concentration), and the elimination rate constant of the nonsaturable component $\left(k_{\mathrm{el}, \mathrm{Ns}}\right)$ was $4.04 \times$ $10^{-3} \min ^{-1}$.

\section{Effect of aging on $A \beta(1-40)$ elimination from rat brain}

To examine the effect of aging, the $A \beta(1-40)$ elimination rate was determined in 7-week-old and 23-month-old rats. The $k_{\text {app,el }}$ value was significantly reduced by $30.5 \pm 5.9 \%(n=3-4$; mean \pm SEM) in 23-month-old rats compared with that in 7 -week-old rats $(p<0.01)$.

\section{HPLC analysis of radioactivity in plasma}

The ${ }^{125}$ I radioactivity in jugular venous plasma at $5 \mathrm{~min}$ after intracerebral microinjection was analyzed by HPLC (Fig. 2). The radioactivity was recovered in two peaks by gel filtration (Fig. $2 A$ ). In fraction 8 , the radioactivity was recovered at the same retention time as $\mathrm{A} \beta(1-40)$ (Fig. $2 B$ ). Assuming that the gel filtration fractions $5-11$ all contain the same ratio of intact $A \beta(1-$ 40 ) and metabolite as fraction $8,17.7 \%$ of the radioactivity recovered from plasma was estimated to be attributable to intact $\left[{ }^{125} \mathrm{I}\right] \mathrm{A} \beta(1-40)$. No significant radioactivity was detected at the retention time of $\mathrm{A} \beta(1-40)$ in fraction 17.

\section{Effects of L-tyrosine, RAP, and fucoidan on}

A $\boldsymbol{\beta}(1-40)$ elimination

The $k_{\text {app,el }}$ value of $\left[{ }^{125} \mathrm{I}\right] \mathrm{A} \beta(1-40)$ was not affected by the preadministration of L-tyrosine or by the coadministration of RAP, a ligand of all LDL receptor families (such as LRP-1), and fucoidan, a scavenger receptor type A (SR-A) ligand (Table 1). To confirm the lack of involvement of LDL receptors, RAP $(5 \mu \mathrm{M})$ was ad- ministered just before microinjection of $\left[{ }^{125} \mathrm{I}\right] \mathrm{A} \beta(1-40)$ at the same brain region. The relative remaining percentages of $\left[{ }^{125} \mathrm{I}\right] \mathrm{A} \beta(1-40)$ at $60 \mathrm{~min}$ were $34.1 \pm 2.8$ and $37.2 \pm 1.4 \%$ in the cases of preadministration of buffer and RAP, respectively. Preadministration of RAP did not affect $\left.{ }^{[25} \mathrm{I}\right] \mathrm{A} \beta(1-40)$ elimination.

\section{Involvement of NEP and an insulin-sensitive process in A $\boldsymbol{\beta}(1-40)$ elimination}

The coadministration of thiorphan, an inhibitor of NEP, significantly decreased the $k_{\text {app,el }}$ value of $\left[{ }^{125} \mathrm{I}\right] \mathrm{A} \beta(1-40)$ by $34.0 \%$ (Table 1). The clearance rate of [ $\left.{ }^{125} \mathrm{I}\right] \mathrm{A} \beta(1-40)$ was dose dependently inhibited by insulin, and the $k_{\text {app,el }}$ value was significantly decreased by $44.6 \%(100 \mu \mathrm{g} / \mathrm{ml}$ in injectate) (Fig. 3).

To evaluate the involvement of IR and IGFIR, AG1024, a specific inhibitor of IR and IGFIR kinase and autophosphorylation $\left(\mathrm{IC}_{50}\right.$ values of AG1024 for IR and IGFIR were 57 and $7 \mu \mathrm{M}$, respectively) (Parrizas et al., 1997), or an antibody against the receptor was injected together with $\left[{ }^{125} \mathrm{I}\right] \mathrm{A} \beta(1-40)$ (Table 1). AG1024 $(100 \mu \mathrm{g} / \mathrm{ml})$ and anti-IGFIR antibody $(100 \mu \mathrm{g} / \mathrm{ml}) \mathrm{did}$ not significantly affect the elimination rate of $\left[{ }^{125} \mathrm{I}\right] \mathrm{A} \beta(1-40)$. To confirm the lack of involvement of these receptors, AG1024 (100 $\mu \mathrm{g} / \mathrm{ml} ; 328 \mu \mathrm{M}$ ) was preadministered just before microinjection of $\left[{ }^{125} \mathrm{I}\right] \mathrm{A} \beta(1-40)$ at the same brain region. The relative remaining percentages of $\left[{ }^{125} \mathrm{I}\right] \mathrm{A} \beta(1-40)$ at 60 min were $44.4 \pm 2.7$ and $45.1 \pm 1.8 \%$ for preadministration of buffer and AG1024, respectively, indicating that AG1024 did not affect $\left[{ }^{125} \mathrm{I}\right] \mathrm{A} \beta(1-40)$ clearance.

To evaluate the involvement of IDE, the effect of IDE inhibitors on the elimination rate was examined by preadministration (Table 2). Bacitracin reduced the elimination rate by $76.7 \%$ ( $p=$ 0.0506), whereas neither $\mathrm{N}$-ethylmaleimide, 1,10-phenanthroline, nor EDTA significantly reduced the elimination rate.

\section{Direct binding of insulin with $A \beta(1-40)$}

To clarify whether insulin binds directly to $\mathrm{A} \beta(1-40)$, resulting in inhibition of $\mathrm{A} \beta(1-40)$ elimination, ultrafiltration of $\left[{ }^{125} \mathrm{I}\right] \mathrm{A} \beta(1-40)$ in the presence or absence of insulin $(100 \mu \mathrm{g} / \mathrm{ml})$ was performed. The recovery of $\left[{ }^{125} \mathrm{I}\right]$ insulin in the filtrate without $\mathrm{A} \beta(1-40)$ was $0.6 \pm 0.0 \%(n=3$; mean \pm SEM $)$, indicating that insulin did not pass through the filter under this condition. The recoveries of $\left[{ }^{125} \mathrm{I}\right] \mathrm{A} \beta(1-40)$ in the filtrates were $21.4 \pm 1.0$ and $22.3 \pm 0.5 \%(n=3$; mean \pm SEM $)$ in the presence and absence of insulin, respectively.

\section{Effect of insulin on remaining intact $\mathrm{A} \boldsymbol{\beta}(1-40)$ in the brain}

The effect of insulin on the level of intact $\left[{ }^{125} \mathrm{I}\right] \mathrm{A} \beta(1-40)$ in the brain was estimated by SDS-PAGE analysis of radioactivity remaining in the brain at $30 \mathrm{~min}$ after microinjection. The radioactivity of intact $\left[{ }^{125} \mathrm{I}\right] \mathrm{A} \beta(1-40)$ amounted to $60.6 \pm 3.5$ and $27.0 \pm 1.8 \%(n=4$; mean \pm SEM $)$ of total radioactivity in the presence and absence of insulin $(100 \mu \mathrm{g} / \mathrm{ml})$, respectively.

\section{Discussion}

The present study demonstrates that an insulin-sensitive cerebral $\mathrm{A} \beta(1-40)$ clearance process exists in the brain of rats. The $\mathrm{A} \beta(1-$ 40) elimination rate is concentration dependent with a $K_{\mathrm{m}}$ value of $247 \mathrm{~nm}$ (injectate concentration) or $8.15 \mathrm{~nm}$ (cerebral concentration; the injectate is diluted 30.3-fold by diffusion in the brain) (Fig. 1B) (Kakee et al., 1996). The kinetic parameters $\left(K_{\mathrm{m}}\right.$ and $\left.k_{\text {app,el }}\right)$ of $\mathrm{A} \beta(1-40)$ elimination in the rat brain found in this study are very similar to those reported for mouse brain (Shibata et al., 2000). Furthermore, the elimination rate of $A \beta(1-40)$ was 

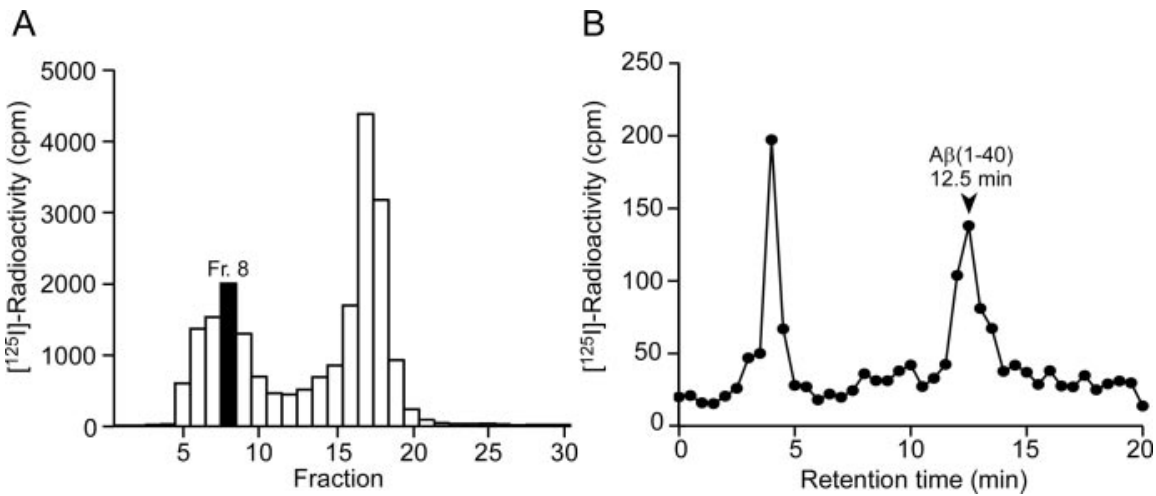

Figure 2. Analysis of radioactivity in plasma after intracerebral administration of [ $\left.{ }^{125} \mathrm{I}\right] \mathrm{A} \beta(1-40)$. Venous blood was collected from the ipsilateral jugular vein at 5 min after the microinjection. $A$, Radioactivity of gel-filtered plasma fractions. $B, H P L C$ analysis of fraction 8 in the gel-filtered fractions. A standard sample of $A \beta(1-40)$ was eluted at $12.5 \mathrm{~min}$, as indicated by the arrowhead.

Table 1. Effects of various compounds on the elimination rate of $\left[{ }^{125} I\right] A \beta(1-40)$ from rat brain

\begin{tabular}{lc}
\hline Inhibitor & $\begin{array}{l}\text { Apparent elimination rate constant } \\
\left(k_{\text {app }, e l}\right)\end{array}$ \\
\hline Control & $100.0 \pm 5.0$ \\
RAP $(5 \mu \mathrm{m})$ & $109.9 \pm 7.1$ \\
L-Tyrosine $(2 \mathrm{~mm})$ & $98.0 \pm 14.3$ \\
Fucoidan $(100 \mu \mathrm{g} / \mathrm{ml})$ & $98.5 \pm 10.0$ \\
Thiorphan $(1 \mathrm{~mm})$ & $66.0 \pm 5.0^{*}$ \\
AG1024 $(100 \mu \mathrm{g} / \mathrm{ml})$ & $110.0 \pm 11.3$ \\
Anti-IGFIR $(100 \mu \mathrm{g} / \mathrm{ml})$ & $101.9 \pm 7.0$ \\
\hline
\end{tabular}

RAP, fucoidan, thiorphan, AG1024, and anti-IGFIR were each administered simultaneously with [ ${ }^{125}$ I] $A \beta(1-40)$ and $\left[{ }^{14} \mathrm{C}\right]$ inulin. $\mathrm{L}$-Tyrosine was preadministered before $\left[{ }^{125} \mid\right] \mathrm{A} \beta(1-40)$ and $\left[{ }^{14} \mathrm{C}\right]$ inulin administration. The clearance was evaluated as $k_{\text {app,el| }}$. Each value represents the mean \pm SEM $(n=3-8) .{ }^{*} p<0.01$, significantly different from the control.

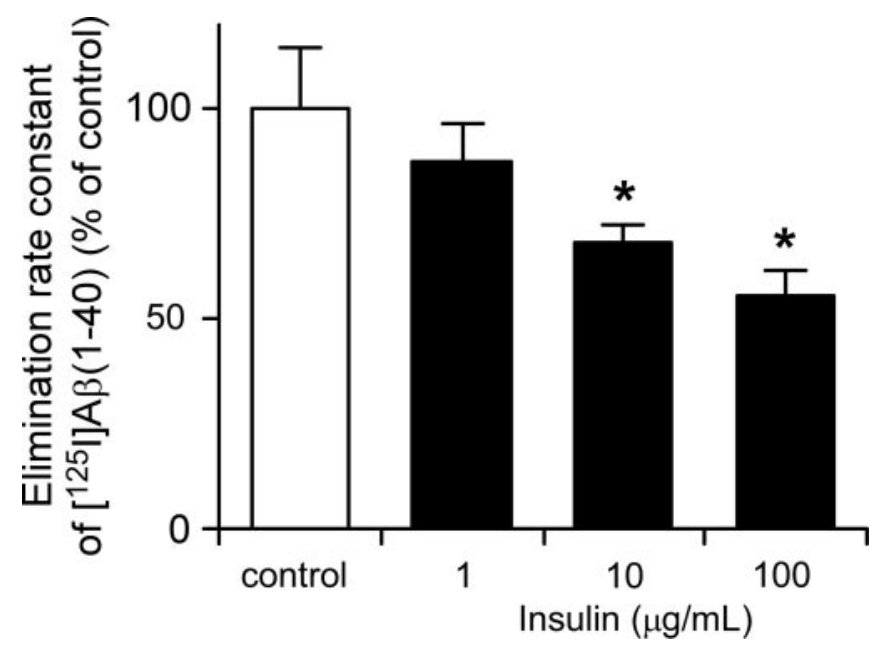

Figure 3. Effects of insulin on the elimination rate of $\left[{ }^{125} \mathrm{l}\right] \mathrm{A} \beta(1-40)$ from rat brain. Insulin $(1,10$, and $100 \mu \mathrm{g} / \mathrm{ml})$ was administered simultaneously with [ $\left.{ }^{125} \mathrm{I}\right] \mathrm{A} \beta(1-40)$ into the brain. Each column represents the mean $\pm \operatorname{SEM}(n=3) .{ }^{*} p<0.01$, significantly different from the control.

reduced in aged rats, as it was in aged mice (Shibata et al., 2000). These results indicate that the characteristics of cerebral $A \beta(1-$ 40) clearance from the brain in rat are similar to those in mouse.

Part of the $A \beta(1-40)$ was detected in intact form in plasma after intracerebral administration (Fig. 2). Although the amount of intact $A \beta(1-40)$ crossing the BBB into the blood could not be accurately estimated because of degradation and rapid elimination of $A \beta(1-40)$ (Poduslo et al., 1999; Hone et al., 2003), this result indicates the existence of a transport system, such as receptor-mediated transcytosis and/or carrier-mediated transport, for intact $\mathrm{A} \beta(1-40)$ at the $\mathrm{BBB}$. In contrast, inhibitors of proteases involved in the proteolytic $\mathrm{A} \beta$-degrading system, thiorphan and insulin, exhibited an inhibitory effect on the elimination rate of A $\beta(1-40)$ (Fig. 3, Table 1). Furthermore, the degradation of $\mathrm{A} \beta(1-40)$ was observed in the brain. Overall, it appears that a degradation process is involved in the cerebral $A \beta(1-40)$ clearance and that the $\mathrm{BBB}$ possesses a transport system for not only intact but also degraded $\mathrm{A} \beta(1-40)$.

A transport system for large neutral amino acids exists at brain capillary endothelial cells (Hargreaves and Pardridge, 1988). Therefore, it is conceivable that ${ }^{125} \mathrm{I}$-linked L-tyrosine produced from degraded $\mathrm{A} \beta(1-40)$ undergoes brain-to-blood efflux at the BBB. As shown in Table 1 , the elimination rate of $A \beta(1-40)$ was not affected by L-tyrosine, suggesting that the involvement of large neutral amino acid transport in the clearance is negligible, and consequently, clearance of degraded $A \beta(1-40)$ is likely to be mediated by the transport system for peptide fragments.

NEP null mouse showed an approximately twofold increase of $\mathrm{A} \beta(1-42)$ and $\mathrm{A} \beta(1-40)$ in the brain, and a NEP inhibitor, thiorphan, inhibited degradation of exogenous $\left[{ }^{3} \mathrm{H} /{ }^{14} \mathrm{C}\right] \mathrm{A} \beta(1-42)$ in rat brain (Iwata et al., 2000). These results support the view that the inhibitory effect of thiorphan on the elimination rate of $\mathrm{A} \beta(1-40)$ reflects the inhibition of degradation by NEP. The contribution of NEP to cerebral $\mathrm{A} \beta(1-40)$ clearance in the brain may not be $>34 \%$, based on the inhibitory effect of thiorphan on the clearance (Table 1$)$. The $K_{\mathrm{m}}$ value of NEP for $\mathrm{A} \beta(1-40)$ is $11.2 \mu \mathrm{M}$ (Perez et al., 2000; Shirotani et al., 2001), which is $\sim 1000$-fold greater than that of the saturable process observed in Figure $1 B$. Therefore, it is likely that the clearance process involving NEP consists of a nonsaturable (low-affinity) process and/or that degraded $\mathrm{A} \beta(1-40)$ fragments inhibit their efflux transport in the same way that intact $\mathrm{A} \beta(1-40)$ inhibits its efflux transport.

Insulin significantly inhibited the elimination rate of $\mathrm{A} \beta(1-$ 40 ) and increased the level of intact $A \beta(1-40)$ in rat brain (Fig. $3)$. This is the first in vivo demonstration of insulin-sensitive cerebral A $\beta$ clearance. Insulin treatment in diabetes increases the risk of dementia (Ott et al., 1999), and insulin infusion led to an increase in CSF $\mathrm{A} \beta(1-42)$ levels, which may reflect brain $\mathrm{A} \beta$ levels, in normal older adults (Watson et al., 2003). It is possible that the inhibition of the cerebral $\mathrm{A} \beta(1-40)$ clearance process by insulin causes accumulation of $\mathrm{A} \beta(1-40)$ in the brain and accelerates $\mathrm{AD}$. The brain insulin level in normal adults is $\sim 0.5 \mathrm{ng} / \mathrm{mg}$ protein ( $50 \mathrm{ng} / \mathrm{gm}$ brain). Insulin infusion results in an $\sim 10$-fold increase in the plasma insulin level (Frolich et al., 1998; Watson et al., 2003), and, in the present study, $300 \mathrm{ng} / \mathrm{ml}$ insulin (cerebral concentration) significantly inhibited the $\mathrm{A} \beta(1-40)$ elimination rate (Fig. 3). Although brain insulin levels in treated patients have not been determined, insulin treatment in older patients might affect their cerebral $\mathrm{A} \beta$ clearance to some extent by increasing brain insulin and aging.

The inhibitory effects of insulin can be explained by the inhibitory effect of insulin on the brain-to-blood efflux of intact $A \beta(1-$ 40 ) and/or proteolytic degradation. The brain capillary endothelial cells express IR, which mediates transport of insulin across the BBB by transcytosis (Pardridge et al., 1995). The IR may play a 
Table 2. Effects of inhibitors for IDE on the elimination rate of $\left[{ }^{125} I\right] A \beta(1-40)$ from rat brain

\begin{tabular}{lc}
\hline Inhibitor & $\begin{array}{c}\text { Apparent elimination rate constant } \\
\left(k_{\text {app,el }}\right) \text { (percentage of control) }\end{array}$ \\
\hline Control & $100.0 \pm 6.8$ \\
Bacitracin $(1 \mathrm{mg} / \mathrm{ml})$ & $76.7 \pm 8.9$ \\
$N$-ethylmaleimide $(1 \mathrm{~mm})$ & $106.8 \pm 5.5$ \\
Control (PBS) $^{a}$ & $100.0 \pm 7.1$ \\
$1,10-$ Phenanthroline $(1 \mathrm{~mm})^{a}$ & $99.4 \pm 15.4$ \\
${\text { EDTA }(5 \mathrm{~mm})^{a}}^{a}$ & $98.1 \pm 12.8$
\end{tabular}

Bacitracin, $N$-ethylmaleimide, 1,10-phenanthroline, and EDTA were each preadministered before $\left[{ }^{125} \mid\right] A \beta(1-40)$ and $\left[{ }^{14} \mathrm{C}\right]$ inulin administration. The clearance was evaluated as $k_{\text {app,el: }}$ Each value represents the mean $\pm \operatorname{SEM}(n=3)$. ${ }^{a}$ The elimination rate was examined in the presence of 1,10-phenanthroline or EDTA dissolved in PBS.

role in this efflux transport at the BBB, because $\mathrm{A} \beta(1-40)$ competes for insulin binding to the IR (Xie et al., 2002). However, AG1024, a specific inhibitor of IR kinase and autophosphorylation, which is requisite for many of the biological effects of IR including endocytosis (Kublaoui et al., 1995), failed to affect the $\mathrm{A} \beta(1-40)$ elimination rate (Table 1$)$. Insulin is a ligand for IGFIR (Stracke et al., 1989), and IGFIR is expressed at the BBB (Duffy et al., 1988). However, anti-IGFIR antibody, which can neutralize IGFIR signaling (Rohlik et al., 1987), failed to affect the $A \beta(1-$ 40) elimination rate (Table 1). These results indicate that IR and IGFIR do not make a major contribution to cerebral $\mathrm{A} \beta(1-40)$ clearance. Carro et al. (2002) have reported that IGF-I treatment reduces the brain $A \beta$ levels via CSF flow by enhancing the permeability of $\mathrm{A} \beta$ carrier protein, such as albumin and transthyretin, across the choroids plexus epithelial cells that form the bloodCSF barrier. However, the contribution of IGFI-R to the $A \beta(1-$ 40) clearance process at the $\mathrm{BBB}$ is small, and the $\mathrm{BBB}$ permeability measured by $\left[{ }^{14} \mathrm{C}\right]$ inulin was not affected by insulin (data not shown), suggesting that insulin and IGF-I have different effects at the BBB and choroid plexus. The possibility should also be considered that insulin directly binds with $\mathrm{A} \beta(1-40)$, but the results of the ultrafiltration study indicate that this is not the case.

The involvement of IDE in the cerebral $A \beta(1-40)$ clearance was considerable, because insulin inhibits $A \beta$ degradation by IDE. The $\mathrm{IC}_{50}$ value of insulin for cerebral $\mathrm{A} \beta(1-40)$ elimination rate $(3.47 \mu \mathrm{g} / \mathrm{ml}$ in injectate concentration or $115 \mathrm{ng} / \mathrm{ml}$ in cerebral concentration) is close to that for IDE (145 ng/ml; $25 \mathrm{nM}$ ) (Affholter et al., 1990), if it is assumed that $100 \mu \mathrm{g} / \mathrm{ml}$ insulin fully inhibits the sensitive process (Fig. 3). Furthermore, bacitracin, an inhibitor for IDE, inhibited the elimination rate (Table 2). These results support the involvement of IDE in the cerebral A $\beta(1-40)$ clearance. However, $N$-ethylmaleimide (thiol active agent), 1,10phenanthroline, and EDTA (metal chelators) did not significantly reduce the elimination rate, although they are inhibitors of IDE (Table 2$)$. In addition, IDE cleaves $A \beta(1-40)$ and $A \beta(1-42)$, and both proteolytic activities were inhibited by insulin $(5.80$ $\mathrm{mg} / \mathrm{ml} ; 1 \mu \mathrm{M}$ ) (Perez et al., 2000), whereas Iwata et al. (2000) reported that $10 \mathrm{mg} / \mathrm{ml}$ insulin did not affect the degradation of exogenous $\left[{ }^{3} \mathrm{H} /{ }^{14} \mathrm{C}\right] \mathrm{A} \beta(1-42)$ in rat brain. The known molecules cannot fully explain the mechanism of insulin-sensitive cerebral $\mathrm{A} \beta(1-40)$ clearance, and the involvement of some unknown transport system or proteases must also be considerable. Additional studies are necessary to clarify the molecule(s) responsible for the insulin-sensitive cerebral $\mathrm{A} \beta(1-40)$ clearance.

The age-dependent attenuation of $\mathrm{A} \beta$ elimination rate from the brain explains that aging is one of the risk factors for $\mathrm{AD}$. LRP-1 has been reported to be involved in the brain-to-blood efflux transport of $\mathrm{A} \beta(1-40)$ at the $\mathrm{BBB}$, and its expression at the brain capillary endothelial cells is reduced in aged mouse brain.
Nevertheless, the elimination rate of $\mathrm{A} \beta(1-40)$ was not inhibited by RAP in rat (Table 1), suggesting that, at least in rat, LRP-1 does not make a major contribution to the brain-to-blood efflux transport of $A \beta(1-40)$ or the age-dependent attenuation of the cerebral A $\beta(1-40)$ clearance. The levels of NEP protein in cortex showed no change between 7-month-old and 22-month-old mice (Apelt et al., 2003). Therefore, other clearance processes, including the brain-to-blood efflux transport of intact $\mathrm{A} \beta(1-40)$ and/or the insulin-sensitive clearance process, appear to be attenuated depending on aging.

LRP-1 and SR-A made no significant contribution to A $\beta(1-$ 40) elimination in rats (Table 1 ). Shibata et al. (2000) reported that $5 \mu \mathrm{M}$ RAP inhibited the $\mathrm{A} \beta(1-40)$ elimination rate, whereas $100 \mu \mathrm{g} / \mathrm{ml}$ fucoidan enhanced it; they used the same concentrations that we used. Furthermore, they reported that most of the injected $A \beta(1-40)$ remained intact after $60 \mathrm{~min}$, whereas degradation of $A \beta(1-40)$ and $A \beta(1-42)$ was observed in rat brain after $30 \mathrm{~min}$ (Table 2) (Iwata et al., 2000). These different effects might be attributed to the difference in the modes of cerebral administration of $\left[{ }^{125} \mathrm{I}\right] \mathrm{A} \beta(1-40)$ (i.e., microinjection into the Par2 region in our rat study) but into the caudate nucleus at 1 week after cannulation in their mouse study.

In conclusion, the present study has demonstrated the involvement of a proteolytic degradation process and an insulinsensitive process in cerebral $\mathrm{A} \beta(1-40)$ clearance to the blood in rats. This novel information on cerebral $A \beta(1-40)$ clearance could have implications for the treatment of $\mathrm{AD}$ and diabetes with insulin.

\section{References}

Affholter JA, Cascieri MA, Bayne ML, Brange J, Casaretto M, Roth RA (1990) Identification of residues in the insulin molecule important for binding to insulin-degrading enzyme. Biochemistry 29:7727-7733.

Apelt J, Ach K, Schliebs R (2003) Aging-related down-regulation of neprilysin, a putative $\beta$-amyloid-degrading enzyme, in transgenic Tg2576 Alzheimer-like mouse brain is accompanied by an astroglial upregulation in the vicinity of $\beta$-amyloid plaques. Neurosci Lett 339:183-186.

Carro E, Trejo JL, Gomez-Isla T, LeRoith D, Torres-Aleman I (2002) Serum insulin-like growth factor I regulates brain amyloid- $\beta$ levels. Nat Med 8:1390-1397.

Duffy KR, Pardridge WM, Rosenfeld RG (1988) Human blood-brain barrier insulin-like growth factor receptor. Metabolism 37:136-140.

Frolich L, Blum-Degen D, Bernstein HG, Engelsberger S, Humrich J, Laufer S, Muschner D, Thalheimer A, Turk A, Hoyer S, Zochling R, Boissl KW, Jellinger K, Riederer P (1998) Brain insulin and insulin receptors in aging and sporadic Alzheimer's disease. J Neural Transm 105:423-438.

Hargreaves KM, Pardridge WM (1988) Neutral amino acid transport at the human blood-brain barrier. J Biol Chem 263:19392-19397.

Hone E, Martins IJ, Fonte J, Martins RN (2003) Apolipoprotein E influences amyloid- $\beta$ clearance from the murine periphery. J Alzheimers Dis 5:1-8.

Hosoya K, Ohtsuki S, Terasaki T (2002) Recent advances in the brain-toblood efflux transport across the blood-brain barrier. Int J Pharm 248:15-29.

Iwata N, Tsubuki S, Takaki Y, Watanabe K, Sekiguchi M, Hosoki E, Kawashima-Morishima M, Lee HJ, Hama E, Sekine-Aizawa Y, Saido TC (2000) Identification of the major A $\beta 1-42$-degrading catabolic pathway in brain parenchyma: suppression leads to biochemical and pathological deposition. Nat Med 6:143-150.

Kakee A, Terasaki T, Sugiyama Y (1996) Brain efflux index as a novel method of analyzing efflux transport at the blood-brain barrier. J Pharmacol Exp Ther 277:1550-1559.

Kublaoui B, Lee J, Pilch PF (1995) Dynamics of signaling during insulinstimulated endocytosis of its receptor in adipocytes. J Biol Chem 270:59-65.

Ott A, Stolk RP, van Harskamp F, Pols HA, Hofman A, Breteler MM (1999) Diabetes mellitus and the risk of dementia: the Rotterdam study. Neurology 53:1937-1942.

Pardridge WM, Kang YS, Buciak JL, Yang J (1995) Human insulin receptor 
monoclonal antibody undergoes high affinity binding to human brain capillaries in vitro and rapid transcytosis through the blood-brain barrier in vivo in the primate. Pharm Res 12:807-816.

Parrizas M, Gazit A, Levitzki A, Wertheimer E, LeRoith D (1997) Specific inhibition of insulin-like growth factor-1 and insulin receptor tyrosine kinase activity and biological function by tyrphostins. Endocrinology 138:1427-1433.

Perez A, Morelli L, Cresto JC, Castano EM (2000) Degradation of soluble amyloid $\beta$-peptides $1-40,1-42$, and the Dutch variant $1-40 \mathrm{Q}$ by insulin degrading enzyme from Alzheimer disease and control brains. Neurochem Res 25:247-255.

Poduslo JF, Curran GL, Sanyal B, Selkoe DJ (1999) Receptor-mediated transport of human amyloid $\beta$-protein $1-40$ and $1-42$ at the blood-brain barrier. Neurobiol Dis 6:190-199.

Qiu WQ, Walsh DM, Ye Z, Vekrellis K, Zhang J, Podlisny MB, Rosner MR, Safavi A, Hersh LB, Selkoe DJ (1998) Insulin-degrading enzyme regulates extracellular levels of amyloid $\beta$-protein by degradation. J Biol Chem 273:32730-32738.

Rohlik QT, Adams D, Kull Jr FC, Jacobs S (1987) An antibody to the receptor for insulin-like growth factor I inhibits the growth of MCF-7 cells in tissue culture. Biochem Biophys Res Commun 149:276-281.

Selkoe DJ (2001) Clearing the brain's amyloid cobwebs. Neuron $32: 177-180$
Shibata M, Yamada S, Kumar SR, Calero M, Bading J, Frangione B, Holtzman DM, Miller CA, Strickland DK, Ghiso J, Zlokovic BV (2000) Clearance of Alzheimer's amyloid- $\beta_{(1-40)}$ peptide from brain by LDL receptorrelated protein-1 at the blood-brain barrier. J Clin Invest 106:1489-1499.

Shirotani K, Tsubuki S, Iwata N, Takaki Y, Harigaya W, Maruyama K, KiryuSeo S, Kiyama H, Iwata H, Tomita T, Iwatsubo T, Saido TC (2001) Neprilysin degrades both amyloid $\beta$ peptides $1-40$ and 1-42 most rapidly and efficiently among thiorphan- and phosphoramidon-sensitive endopeptidases. J Biol Chem 276:21895-21901.

Stracke ML, Engel JD, Wilson LW, Rechler MM, Liotta LA, Schiffmann E (1989) The type I insulin-like growth factor receptor is a motility receptor in human melanoma cells. J Biol Chem 264:21544-21549.

Watson GS, Peskind ER, Asthana S, Purganan K, Wait C, Chapman D, Schwartz MW, Plymate S, Craft S (2003) Insulin increases CSF A $\beta 42$ levels in normal older adults. Neurology 60:1899-1903.

Xie L, Helmerhorst E, Taddei K, Plewright B, Van Bronswijk W, Martins R (2002) Alzheimer's $\beta$-amyloid peptides compete for insulin binding to the insulin receptor. J Neurosci 22:RC221(1-5).

Zhang Y, Pardridge WM (2001a) Mediated efflux of IgG molecules from brain to blood across the blood-brain barrier. J Neuroimmunol 114:168-172.

Zhang Y, Pardridge WM (2001b) Rapid transferrin efflux from brain to blood across the blood-brain barrier. J Neurochem 76:1597-1600. 